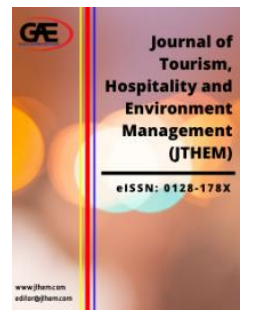

\title{
SENIOR TOURISM AND CHANCE FOR TOURISM BUSINESS PLAYERS
}

\author{
Farma Mangunsong ${ }^{1}$ \\ 1 Institute for Population and Social Research (IPSR), Mahidol University, Thailand. \\ Email: farma.mangunsong@gmail.com
}

\section{Article Info: \\ Article history: \\ Received date: 17.03 .2020 \\ Revised date: 24.03.2020 \\ Accepted date: 31.03 .2020 \\ Published date: 10.06 .2020 \\ To cite this document: \\ Mangunsong, F. (2020). Senior Tourism and Chance for Tourism Business Players. Journal of Tourism, Hospitality and Environment Management, 5 (19), 01-13.}

DOI: 10.35631/JTHEM.519001.

\begin{abstract}
:
Increasing the number of elderly people in the world creates an opportunity for the tourism business. To be in line with this, business players in the tourism sector have to cope with their social demographic factors such as age, gender, income, cultural values, and also promotion methods to promote senior tourism. The objective of this study is to describe the social demographic characteristics and needs of potential elderly people so that business players can utilize the phenomena and collected information as a benefit to promote tourism for elderly people or senior tourism. This study used SWOT analysis to identify strength, weakness, opportunity, and threat of senior tourism business as well as to formulate strategies for senior tourism. The literature review was conducted to collect information about elderly people having senior tourism. It is found that social demographic characteristics influence the needs and motivation of elderly people in senior tourism. Senior tourists from highincome levels need high quality of service, beautiful scenery, and privacy while those from middle-income levels prefer attractions and festivals. Senior tourists with "young at heart" prefer more challenging activities as well as younger and male senior tourists, while those with "old at heart" put higher concern on convenience and security as well as older and female tourists. Leisure, cultural values, and personal achievement motivate elderly people to have senior tourism. Leisure with family and parents motivates senior tourism in Asia but living away from materialistic life is more appropriate for western people. Creating several traveling packages to adapt to various characteristics of elderly people will enlarge the market for the tourism sector. Providing better facilities adopting physical need of elderly people make them confident to travel. Business players can use digital social media to promote senior tourism to elderly people as well as to current adult children since current old parents experience higher technological exposure rather than their previous counterparts.
\end{abstract}

\section{Keywords:}

Elderly People, Leisure, Travelling, Life Satisfaction, SWOT 


\section{Introduction}

People usually have more spare time when they get older rather than when they were at young generation (Pegg, 2009; Zhang and Zhang, 2018). When people are young, they use most their time for productive activities such as for working, doing business, and taking care family. They spend time for travelling sometime, but they had to plan it properly before the holiday time come because their work schedule and family matters are constraints for travelling. Although they can go travelling, work and family matters limit holiday time. They have to allocate time for working at office, spouse activities, and school time of children. Taking care children and dealing with family obligations took their time to focus on family matters (Albayrak et al., 2016).

They could be very busy with their work when they were in active era but have longer time after retirement. When children become adults and independent, parents have more time for themselves because they do not have to take care children as intensive as when children were in childhood (Ferrer et al., 2016). Family obligation decreases as children are able to take care themselves. After retirement, they have more time because they do not have to work and less obligation in working (Nimrod, 2008). For women that have finished obligation to take care young children, having tourism activity is like a reward in retirement time from that family obligation (Pesonen and Komppula, 2010).

One of alternatives to fill elderly people's spare time is travelling and many studies show benefits from travelling for older people or senior tourism. Travelling yields positive impact on life satisfaction because of feeling of perceived health (Ferrer, 2016) and results positive life satisfaction in leisure (Woo et al., 2016). Thus, having travelling activities will benefit their quality of life.

For tourism business, travelling for elderly people is a big opportunity since number of aging people is increasing (Albayrak et al., 2016; Gonzales et al., 2017). Increase in number of aging people is a market for tourism business. According to the United Nations (2017), number of older persons aged 60 or over in 1980 has been more doubled in 2017 (382 million versus 962 million) and in 2050, it is projected that the number will be doubled to 2.1 million. Two thirds of older person worldwide live in developing countries. In 2050, there will be 8 in 10 old people in developing countries.

Travelling yields benefits for old people. Travelling makes them have leisure (Zhang and Zhang, 2018), learn new knowledge (Nimrod, 2008), and feel life achievement ((Lemmetyinen et al., 2016). Besides increasing number of old populations, benefits from travelling for elderly people are features that can be promoted. Business units in tourism sector should take advantage from existing demographic change.

Definition of old person or elderly people may not the same for each country or institution. The United Nations agreed that 60 years old is the cut off to define elderly people (World Health Organization, 2019). Meanwhile, a study in Japan proposed that person aged 65 years old or over is defined as old person (Ouchi et al., 2017). Literatures in this paper mostly used 60 as minimum age for elderly people.

Purpose of this literature review is to answer three research questions which are:

1. What are social demographic characteristics of potential senior tourism consumers?

2. What are motivations of elderly people in senior tourism?

3. What are needs of elderly people in senior tourism?

Copyright $\odot$ GLOBAL ACADEMIC EXCELLENCE (M) SDN BHD - All rights reserved 
4. What are strengths, weaknesses, opportunities, and strengths in senior tourism?

\section{Methodology}

This paper used literature reviews and SWOT analysis. The literature search used database of SCOPUS, JSTOR, and Taylor \& Francis Online. The literature search covered area of interests such as senior tourism, elderly people, old people, and travelling. To gather information about reasons for travelling of elderly people, some terms were used, such as motivation, reason, and need. To find articles relating with SWOT, search used "swot" term.

SWOT analysis is applied to identify and assess strengths, weaknesses, opportunities, and threats (Valentin, 2001). Further, the assessment is used to formulate strategies to expand business activities regarding business of interest. Various business fields have applied SWOT analysis, such as tour operator (DATAMONITOR, 2005), software (Valentin, 2001), and teaching evaluation (Thomas et al., 2014).

To build strategies written on this paper, this paper adopted SWOT analysis developed by Harvard Business School as written by Chermark \& Kasshanna (2017). There are four strategies offered, which are: (1) achieve opportunities that match strengths; (2) overcome weaknesses to attain opportunities; (3) use strengths to reduce threats; and (4) prevent weaknesses to avoid threats. However, this study focuses more on strengths, thus strategies offered here are: (1) use strengths to create opportunities; (2) use strengths to avert threats; (3) use strengths to compensate weakness; and (4) turn threats into opportunities.

\section{Literature Review}

\section{Socio-Demographic Characteristics Of Potential Senior Tourism Consumers}

There are similar findings on literatures discussing about senior tourism. The elderly people having senior tourisms have longer free time, live in middle-high income level, and have less family and work obligation (Ferrer et al., 2016; Losada et al., 2017; Nimrod, 2008; Woo et al., 2016; Zhang and Zhang, 2018). For elderly people previously worked, retirement from working make them have more free time in daily life. They do not have to go to office anymore and are not burdened by work obligation. Elderly people having adult children have less family obligation because adult children are independent. With adequate spare money in retirement time, they have high purchasing power and are able to travel. Moal-Ulvoas (2017) found that elderly people with travelling experience are those having better financial situation and many new interests, as well as enjoying more consumerist lifestyle. They are different from traditional generation who are more pragmatic, away from technological exposure, and focusing on saving.

Elderly people in populated area tend to have senior tourism. Zhang and Zhang (2018) found that elderly people in populated area in Japan are more likely to travel then their counterpart in depopulated area. Travelling is considered as not common activity for those in depopulated travelling activity including place visits, travel party, and spending money in travel. They have good quality of life in leisure and intimacy because they can participate in friendship, kinship, and organizational activities in their society, thus elderly people in depopulated area are less interesting in tourism activity. To compare between elderly people in populated (urban) and depopulated (rural) area, these reasons may explain why travelling raises quality of life for elderly people that were busy with work (Pegg, 2009). 
Age and gender do not retain older people's willingness to travel. There is no agreement in minimum age level categorized as senior tourists, but there are many studies used pension age depending on each country or minimum 60 (Ferrer et al., 2016; Lee, 2016, Moal-Ulvoas , 2017; Woo et al., 2014), but other studies such as in Taiwan (Lee, 2016) and Spain (Losada et al., 2017) used respondents aged minimum 55 years old or 57 years old in US (Nimrod, 2008) because many of them retired at that age. However, there are some studies reminding not to put high focus on chronological age, but on perceived age. Some elderly people may old physically and mentally, but some of them look, feel, and act younger than their chronological age. Pegg (2009) used term "young at heart" and "old at heart". Type 1 is for elderly people who like tourism for personal achievement, pride, challenges, and fun while the latter is for those highly concern on safety and conventional activities such as safe tracking. Although there are some studies showed difference preference in tourism activity between men and women, but the literatures showed that both of them have interest to travel (Pegg, 2009; Pesonen and Komppula, 2010). Male senior tourists prefer outdoor activities, but female senior tourists prefer convenient activities such as tracking (Pesonen and Komppula, 2010).

\section{Motivations Of Elderly People In Senior Tourism}

Tourism activity is a compensation after retirement from work and family obligation. Previous studies in senior tourism usually relate this topic with tourists who retired from labor market (Albayrak et al., 2016; Ferrer et al., 2016, Gonzales et al., 2014; Pegg, 2009;), although there are some of them also discuss about senior tourism and elderly women finishing taking care their children such study in Finland (Pesonen and Komppula, 2010), or mature elderly people from high economy status in British (Lemmetyinen et al., 2016). With longer free time, adequate spare money and pension income, less family obligation, and no work obligation, they have higher opportunity for travelling. A study in Finland shows that women would like to have tourism after finishing family obligation to take care young children and when children are adult (Pesonen and Komppula, 2010). In China, adult children bring parents to travel as a compensation for taking care children where they were young (Wang et al., 2018). Giving compensation from children to parents is part of family-oriented motivation in traditional spiritual life.

Experiencing leisure is one of motivations why elderly people would like to involve in tourism activity in retirement time. For elderly people in Japan living in populated area, tourism activity affects their quality of life in leisure and quality of life in intimacy (Zhang and Zhang, 2018). By having tourism activity including provide time for place visit and travel party, they can meet friends, kin, or people in the same organization. Meeting and interacting with them are leisure. Importance of leisure and intimacy is for elderly people not only in populated area but also in depopulated area although quality of life in intimacy is higher in the latter as relationship is stronger in that area. Elderly people in Spain also like travelling to visit friend and family (Gonzales et al., 2014). For baby boomer generation born between 1946 and 1964, tourism activity is time to have leisure in term of interacting with people, feeling enjoyment, and experiencing excitement (Pegg, 2009). It contributes to their psychological wellbeing. For mature elderly people, tourism activity is time to socialize with people from similar higheconomy status (Lemmetyinen et al., 2016).

When previous studies show leisure as a motivation for travelling, other studies show positive impact of travelling on leisure and how sharing leisure experience in traveling inspire elderly people to travel. After having dinner with friends and relatives and sharing their leisure experience, their friends plan to travel (Nimrod, 2008). Elderly tourist also can share leisure experience after traveling through social media (Balomenou and Garrod, 2019). Posting on 
social media will be seen by many people easily in one time and influence some of them to travel.

Having spirituality enforces older people to travel. Family togetherness as part of traditional life for Asian people is in line with senior tourism. Adult children in China treat and travel with parents for family togetherness as part of traditional spirituality life (Wang et al., 2018). In line with Confusion, travelling with parents reflects affection from children to parents especially from son to father. For people in Korea, travelling with old parents and family is also form of family engagement (Woo et al., 2016). Not only in Asia, elderly people in France feel spiritual life because they meet tour guide with abundance of knowledge, nice local people with kindness, and other travellers giving them cheerfulness (Moal-Ulvoas, 2017). They learn to appreciate other people because of their kindness.

Feel of personal achievement and pride motivates elderly people for travelling. Young at heartelderly people interpret achievement and pride in thrills, challenges, and fun (Pegg, 2009). They need more challenging activities compared to old at heart counterpart. Visiting new place using different language is also challenging for elderly people in the United States of America (Nimrod, 2008). When they plan to visit new place, they learn new language as preparation. For elderly and mature people in British, one of purposes of having holiday on cruise is for social recognition, prestige, and self-esteem (Lemmetyinen et al., 2016). Their relatives, friends, and colleague will be acknowledged that they just had a luxury travelling that many people may not have the same experience. Sharing this experience also reveals their economy status. For instance, some elderly tourists from Poland are interested in traveling to Japan as it is offered by travel agent as a luxury travel (Sawińska, 2017).

\section{Needs Of Elderly People In Senior Tourism}

Not like younger people who are much more flexible and relax for accommodation and activities in travelling, senior tourists prefer convenient accommodation and destination place. Losada et al., (2017) found that Spanish senior tourists with lower self-perceived health concern about basic health and security services when they choose a hotel. Senior tourists with higher self-perceived income will stay at second home or hotel. Based on this study, choosing a hotel is because they can fulfil the living expense. Safety is also consideration for senior tourists from Taiwan (Lee, 2016). Considering physical condition of elderly people, senior tourists need convenient access to destination and safe destination place. A study of tourists aged 65 and over showed that for German and British tourists staying at five stars-hotel in Turkey concerns about convenient bedroom and location of destination as basic factors (Albayrak et al., 2016).

Regarding hotel location, Spanish senior tourists like hotel located near festival, attraction, historical or artistic place, and art performance (Losada et al., 2017). For them, traveling is a way for intellectual preservation. For Spanish higher-income senior tourists, they prefer staying at second home or apartment surrounded beautiful scenery. This finding is similar to senior female tourists in Finland who look for relaxation, privacy, comfortableness, and beautiful natural environment (Pesonen and Komppula, 2010).

Senior tourists need well-managed and good quality of services and they have purchasing power for the services. They were busy in their previous time, thus now they want to have relax and need assistance from travel agent to manage their travel (Pegg, 2009). For example, senior tourists from Poland need assistance of guidance of attractive place and travel plan at comfortable time (Sawińska, 2017). Travel agent assistance is also needed by senior tourists 
from Spain who are first time travellers and with foreign language limitation so that the agent can help tourists communicate in destination countries (Gonzales et al., 2017). A study in Poland found that quality of services provided by tour leaders and tour agents influence elderly tourists (Sawińska, 2017).

\section{Using Information Of Elderly People For Benefits Of Senior Tourism Business}

Previous studies showed that older persons who do traveling come from middle or high-income level (Albayrak et al., 2016, Ferrer et al., 2016), have more spare time for to travel, discover new experience, and gather with family and friends (Gonzales et al., 2017), and live in populated and urban area (Zhang and Zhang, 2018). They would like to pay for well-managed tourism and good quality of service (Pegg, 2009). Assistance from travel agents in managing their travel will help them because they want to enjoy the journey. For business players in tourism sectors, these characteristics show business opportunity because it is an emerging new demand in tourism sector.

Business players in tourism sector should notice that some customers view travelling as an achievement, others view as a reflection of traditional culture, and the rest treated as part of spiritual life. Since different value is embedded at each person, holiday packages must consider value offered to customer. For instance, travelling is an achievement for older people because it shows that they are still active in old age. They experience old chronological age but perceive younger age because they feel better self-perceived health, independent, and with fewer constraints for traveling (Woo, 2016). They are young at heart although they have aged (Pegg, 2009). This kind of senior tourists prefer thrills, challenge, and fun activities. Some of senior tourists who are old at heart prefer holiday package safer and more conventional activities. Similar with old at heart-tourists, female travellers concern about safety and convenience, but men travellers focus on outdoor activities (Pegg, 2009). For senior tourists from high income level, they need luxury holiday such as on cruise (Lemmetyinen et al., 2016), going abroad (Sawińska, 2017), and staying at a five stars-hotel ((Albayrak et al., 2016). For Asian people, children travelling with parents reflect affection from children for parents (Wang et al., 2018). For western people such as from France, travelling is transcendent from materialistic life (Moal-Ulvoas, 2017).

Not alike their counterparts in the past, current elderly people are more familiar to technology (Moal-Ulvoas, 2017). Encourage customers to share their traveling experience to other people is a marketing strategy that travel agent can pursue. When printed mass media dominated tourism information in the past, current tourists can easily disseminate tourism activity to many people through word of mouth (WoM) by clicking mobile phone, sharing experience on social media, and telling friends on leisure events. Balomenou and Garrod (2019) identified power of photography uploaded on social media on tourism. Using digitalized social media is a collective action and democratization in tourism sector. For elderly people that might be less familiar with social media, sharing tourism experience by having direct meeting at leisure time with customers can be considered. Nimrod (2008) shows that having leisure such as dinner is a way to share traveling experience and influence retires to plan traveling. Lemmetyinen (2016) found that travel agents should notice mature tourists' satisfaction because customers will share experience to others by word of mouth. This study also notices power of brand awareness of choosing travel agent.

At age 60 or over, people may have adult children that can support their parents for travelling. Although target market of senior tourism is elderly people, marketing must not always be intended to them. Since one of purposes of traveling is for family gathering (Nimrod, 2018; 
Wang et al., 2018; Woo et al., 2016), adult children or young generation can become target of promotion. Adult children who are married and have children, or married children are more likely to have travel with their parents (Wang et al., 2018). In culture where family thread is strong like in China, promotion emphasizing family oriented and parent oriented as well as self-oriented will influence young people to travel with parents (Woo et al., 2016).

\section{Strengths, Weaknesses, Opportunities, and Threats in Senior Tourism}

Internal environment and external environment analysis are important to develop strategy to promote senior tourism. In this case, internal environment is strength $(\mathrm{S})$ and weakness $(\mathrm{W})$ of tourism business players. External environment is opportunity $(\mathrm{O})$ and threat $(\mathrm{T})$ of ageing population side. Strength, weakness, opportunity, and threat in senior tourism are described on Figure 1.

Strengths of senior tourism business are experience of business players and network between them. Although senior tourism is new emerging activity in tourism sector, business players or units have been in the market and have experienced in this business. There are three main players in tourism industry which are units managing performance and places of attraction, units managing services such as accommodation and transportation, and travel agents acting as intermediaries between tourists and place of destination. These three business units have their own role in promoting senior tourism.

Weakness in this industry are limitation in places comfortableness for senior tourists. Since senior tourism is a new kind of business in tourism sector, business players in this sector may not have provided accommodations, places of attractions, and transportation modes standard for safety of old people. Current condition of attractive places may not be totally comfortable and safe for elderly people. Climate, length of activity along the days, and variety of activities might not have been attention for business players in senior tourism sector (Sawińska, 2017). Increasing number of ageing population with more time after retirement and family obligation, variety of value of travelling, benefits of senior tourism for elderly people, and technological exposure on elderly people such as cellular phone usage are opportunity to enlarge senior tourism. Holiday packages offered by business players could be various since values of travelling for each customer group vary. Balomenou and Garrod (2019) found power of photography on social media. Since higher number of old people become familiar with cellular hand phone and social media, market size for tourism promotion could be larger than with previous printed conventional media, such as newspapers and advertisement. Fact that senior tourism yields perceived better health (Ferrer, 2016), higher life satisfaction (Woo et al., 2016), and reflection of spirituality (Wong et al., 2016) is an opportunity for business players to promote senior tourism.

Business players in tourism sector must consider some threats which are limitation in physical aspect considering customer age and wider possibility for people to do self-managed traveling since they can access information through online system. They need to feel comfortable, thus facilities, season, and length of activities must be concerns. Autumn and summer seem more suitable for old people rather than winter. Length of activities must be considered as they have physical limitation to travel along the days. 
Figure 1. Strengths, Weaknesses, Opportunities, And Threats (SWOT) In Senior Tourism Business

\begin{tabular}{|c|c|}
\hline \begin{tabular}{ll}
\multicolumn{1}{c}{ Strengths } \\
$\checkmark$ & Business players with experience in \\
tourism sector \\
$\checkmark$ & $\begin{array}{l}\text { Strong network between business } \\
\text { players }\end{array}$
\end{tabular} & \begin{tabular}{ll}
\multicolumn{1}{c}{ Weaknesses } \\
$\checkmark$ & Places of destination have not suited \\
to senior tourists because of lack in \\
comfortableness and safety \\
$\checkmark$ & $\begin{array}{l}\text { Current holiday package that has not } \\
\text { considered climate, length, and } \\
\text { activities suitable for older people }\end{array}$
\end{tabular} \\
\hline \begin{tabular}{ll} 
& \multicolumn{1}{c}{ Opportunities } \\
$\checkmark$ & Increasing number of ageing \\
population with middle/high income, \\
more spare time after retirement and \\
family obligation, many interests \\
$\checkmark$ & More old people familiar with \\
technology such as social \\
media/cellular hand phone \\
$\checkmark \quad$ Benefits of senior tourism in term of \\
perceive better health and life \\
satisfaction \\
$\checkmark \quad$ Different income level and gender \\
$\checkmark$ & Varieties of value of travelling for \\
different customer groups. \\
$\checkmark \quad$ Prosperous adult children with \\
family and parents' orientation, \\
especially in Asia
\end{tabular} & \begin{tabular}{ll}
\multicolumn{1}{c}{ Threats } \\
$\checkmark \quad$ Limitation in physical aspect, \\
season, and length of travel time \\
$\checkmark \quad$ Self-managed traveling as increasing \\
number of elderly people using \\
cellular phone and technology
\end{tabular} \\
\hline
\end{tabular}

There are four big strategies proposed to enlarge senior tourism business as shown at Figure 2. They are use strengths to create opportunities, strengths to avert threats, strengths to compensate weaknesses, turn threats into opportunities.

\section{Use Strengths To Create Opportunities}

Currently, ageing population mainly happen in developed countries, but developing countries will experience the phenomena in the future and most elderly people in the world will leave in developing countries (United Nations, 2017). For now, senior tourism is might be more common in developed countries considering features of potential senior tourists, which are living in middle-high income level, having more free time, and having less family or work obligations. However, promoting senior tourism for people in developing countries can be started soon as number of older people in these areas is growing that follows increase in their purchasing power.

Business players must recognize that there many types of senior tourists. For example, tourists' preference of activities varies based on income, gender, and physical health (Losada et al., 2017; Pegg, 2009). For tourists from middle income level, travel agents can place them at hotel near festival attraction and public performance. For those from high income level, travel agents can provide them accommodation surrounded beautiful scenery, with high privacy, and high quality of service. Tourists from high income might be less reluctant to pay more for this accommodation compared to those from middle income. For a group consisting female senior 
tourists or "old at heart" elderly people, travel agents can create activities giving feel of comfortable such as soft tracking, visiting historical places, and watching performance. Meanwhile, outdoor activities such as outbound and tracking at mountainous area can be set up for male tourists or "young at heart" elderly people. Travel agents should consider different activities for different ages since physical health is different between different age levels. For example, elderly people at age 60-65 may would like to do tracking, but those aged more than 65 might prefer sitting and enjoying performance and scenery.

Create advertisement highlighting values of senior tourism and packaging tourism activity in those values can promote senior tourism. For people in Asia, advertisement that senior tourism is part for spiritual life is important. For them, adult children having holiday with parents is affection from children to parents and reflection of parents-oriented (Wang et al., 2018; Woo et al., 2016). To promote senior tourism in developed countries, advertisement should wrap tourism activity in view of transcendence from materialistic life. Furthermore, finding in Asia also show that senior tourism can be promoted to prosperous adult children.

Business players can use technological and non-technological way such as leisure event to promote this tourism. Giving modest appreciation for sharing travel experience on social media and are ways that travel agent can try. Using social media on cellular phone is more familiar for current adult children and some of current older people. Technology not only promote need of senior tourism, but also make people easier to arrange the holiday and make payment. In the future, technology will play more significantly in senior tourism because current adult people familiar with technology usage will get old.

\section{Use Strengths To Avert Threats}

Travel agents should create tour package containing interesting places, visit schedule, safe accommodation and transportation to persuade elderly people to take the package. This tour package must show difference this package with consideration of elderly people's needs from regular package and its value of money. Safety must be emphasized because elderly tourists who prepare the journey by themselves might neglect security aspect. Travel agents should stress to adult people that senior tourism is a companionship from children to parents.

\section{Use Strengths To Compensate Weaknesses}

As an intermediary between business players in tourism sector, travel agents can push owner of accommodation and place of performance as well as owner of transports to remedy their facility to be suitable with older people's need. For example, path for wheelchair and low distance between stairs should be available.

\section{Turn Threats Into Opportunities}

In current internet era where people can access information about their destination, hotels, and transportation more easily, travel agents should rethink about services attractive for senior tourism that are not found by self-searching. By searching on internet, people can search and choose destinations, reserve hotels, and arrange transportation mode by themselves. Thus, travel agents should offer added value, design unique package, and show the importance in using travel agent for senior tourism.

Since sharing traveling experience will influence targeted elderly people to have senior tourism, institutionalizing simple benefits for promoting previous experience may endorse experienced people to promote senior tourism. Travel agent should think how to use power of social media, leisure activity, and word of mouth to promote senior tourism as a new economy 
opportunity. Giving modest appreciation for sharing travel experience on social media, inviting targeted elderly people for leisure activity such as for dinner, and endorsing previous senior tourists to tell their experience to friends and relatives are ways that travel agent can try.

Figure 2. Strategies Of Travel Agents For Enlarging Senior Tourism Business

\begin{tabular}{|c|c|}
\hline $\begin{array}{l}\text { Strengths to catch Opportunities } \\
\checkmark \text { Promote senior tourism in } \\
\text { developing countries } \\
\checkmark \text { Create holiday package } \\
\text { considering income level, } \\
\text { gender, and physical health. } \\
\checkmark \text { Highlight value of travelling } \\
\text { and differ it for people from } \\
\text { Asia (affection from children } \\
\text { to parents) and Europe } \\
\text { (transcendence from } \\
\text { materialistic life) } \\
\checkmark \text { Stress higher quality of life as } \\
\text { benefit of senior tourism } \\
\checkmark \text { Create leisure event for } \\
\text { current potential elderly } \\
\text { people } \\
\checkmark \text { Use technology to accelerate } \\
\text { senior tourism promotion to } \\
\text { adult children and future older } \\
\text { people }\end{array}$ & $\begin{array}{l}\text { Strengths to avert Threats } \\
\checkmark \text { Create tour package containing } \\
\text { interesting places, visit schedule, } \\
\text { safe accommodation and } \\
\text { transportation to persuade elderly } \\
\text { people to take the package }\end{array}$ \\
\hline $\begin{array}{l}\text { Strengths to compensate Weaknesses } \\
\checkmark \text { Push business players to renovate } \\
\text { accommodation, places of destination } \\
\text { and performance venue to assure that } \\
\text { places visited, and accommodation } \\
\text { occupied by senior tourists support } \\
\text { their need }\end{array}$ & $\begin{array}{l}\text { Threats into Opportunities } \\
\checkmark \text { Promote that traveling by taking tour } \\
\text { package is value for money } \\
\checkmark \quad \text { Promote senior tourism to adult } \\
\text { children that traveling with parents is } \\
\text { a companionship and physical caring } \\
\text { from children from parents } \\
\checkmark \text { Giving modest appreciation for } \\
\text { sharing travel experience on social } \\
\text { media, inviting targeted elderly } \\
\text { people for leisure activity such as for } \\
\text { dinner }\end{array}$ \\
\hline
\end{tabular}

\section{Conclusion}

Increasing number of ageing population around the world, especially in developing countries, is salient opportunity for business players in tourism sector. With higher purchasing power because of their accumulated wealth and more spare time because of retirement and less obligation in family, older persons are a potential to enlarge market for tourism business. Since two-third of elderly people will be in developing countries, this area will be main potential market in the future. 
To catch wider opportunity in senior tourism, business players must notice their social demographic factors and values that make them interest to have travelling. Family and parents oriented is more appropriate to wrap senior tourism in Asia countries while movement from materialistic life is more suitable in western countries. Business players also should consider income, chronological age, age at heart, and gender when they are creating and providing holiday package for customers. Elderly people from higher income prefer high quality service, beautiful scenery, and privacy, but those from middle income prefer location with attractions. Elderly people with old chronological age, feeling of old at heart, and female tend to focus on security and convenience, but those with younger age, feeling young at heart, and males prefer outdoor and challenging activities.

Promotion of senior tourisms should not be intended only for current elderly people, but also to current adult children. There are two reasons for this. First, current adult children with prosperity can give supports to their parents, either in term of financial support or companionship. Second, current adult children will be next elderly people that may have interest to have senior tourism in the future and become future market.

Using technological or non-technological way is important. Current elderly people are more familiar with technology compared to their previous counterparts, thus promotion using technology is possible and easy since current technology only needs finger clicking. However, promotion by inviting elderly people at leisure event could be more preferred. Since current adult children are exposed highly by technology, business players in tourism sector must create innovation to accelerate senior tourism in the future.

\section{References}

Albayrak, T., Caber, M., \& Bideci, M. (2016). Identification of hotel attributes for senior tourists by using Vavra's importance grid. Journal of Hospitality and Tourism Management, 29, 17-23. $\quad 29$ from http://www.sciencedirect.com/science/article/pii/S144767701530067X. doi: https://doi.org/10.1016/j.jhtm.2016.05.004

Balomenou, N., \& Garrod, B. (2019). Photographs in tourism research: Prejudice, power, performance and participant-generated images. Tourism Management, 70, 201-217. Retrieved from http://www.sciencedirect.com/science/article/pii/S0261517718301924. doi: https://doi.org/10.1016/j.tourman.2018.08.014

Chermack, T. J., \& Kasshanna, B. K. (2007). The Use and Misuse of SWOT Analysis and Implications for HRD Professionals. Human Resource Development International, 10(4), 383-399. doi:10.1080/13678860701718760

DATAMONITOR. (2005). SWOT Analysis. MyTravel, PLC SWOT Analysis, 6.

Ferrer, J. G., Sanz, M. F., Ferrandis, E. D., McCabe, S., \& García, J. S. (2016). Social Tourism and Healthy Ageing. International Journal of Tourism Research, 18(4), 297-307. Retrieved from https://onlinelibrary.wiley.com/doi/abs/10.1002/jtr.2048. doi: doi:10.1002/jtr.2048

González, E. A., Sánchez, N. L., \& Vila, T. D. (2017). Activity of older tourists: Understanding their participation in social tourism programs. Journal of Vacation Marketing, 23(4), 295-306. Retrieved

from https://journals.sagepub.com/doi/abs/10.1177/1356766716671165. doi:10.1177/1356766716671165

Lee, C.-F. (2016). An Investigation of Factors Determining Destination Satisfaction and Travel Frequency of Senior Travelers. Journal of Quality Assurance in Hospitality \& Tourism, 17(4), 471-495. Retrieved from 
https://ejournal.mahidol.ac.th/login?url=http://search.ebscohost.com/login.aspx?direct $=$ true $\& \mathrm{db}=$ hjh $\& \mathrm{AN}=119450628 \&$ site $=$ ehost-live.

doi:10.1080/1528008X.2015.1127195

Lemmetyinen, A., Dimitrovski, D., Nieminen, L., \& Pohjola, T. (2016). Cruise destination brand awareness as a moderator in motivation-satisfaction relation. 71(4), 245-258. Retrieved from https://www.emeraldinsight.com/doi/abs/10.1108/TR-07-2016-0027. doi: doi:10.1108/TR-07-2016-0027

Losada, N., Alén, E., Nicolau, J. L., \& Domínguez, T. (2017). Senior tourists' accommodation choices. International Journal of Hospitality Management, 66, 24-34. Retrieved from http://www.sciencedirect.com/science/article/pii/S0278431916304108. doi: https://doi.org/10.1016/j.ijhm.2017.06.014

Moal-Ulvoas, G. (2017). Positive emotions and spirituality in older travelers. Annals of Tourism Research, 66, 151-158. Retrieved from http://www.sciencedirect.com/science/article/pii/S0160738317301111. doi: https://doi.org/10.1016/j.annals.2017.07.020

Nimrod, G. (2008). Retirement and tourism Themes in retirees' narratives. Annals of Tourism Research, 35(4), 859-878. Retrieved from http://www.sciencedirect.com/science/article/pii/S0160738308000480. doi: https://doi.org/10.1016/j.annals.2008.06.001

Nations, U. (2017). World Population Ageing. Available online: https://www.un.org/en/development/desa/population/publications/pdf/ageing/WPA20 17_Report.pdf (accessed on May 14, 2019)

Organization, W. H. (2019). Health situation and trend assessment. http://www.searo.who.int/entity/health_situation_trends/data/chi/elderlypopulation/en/ (accessed on May 13 $\left.{ }^{\text {rd }}, 2019\right)$

Ouchi, Y., Rakugi, H., Arai, H., Akishita, M., Ito, H., Toba, K., . . . elderly, c. o. t. (2017). Redefining the elderly as aged 75 years and older: Proposal from the Joint Committee of Japan Gerontological Society and the Japan Geriatrics Society. 17(7), 1045-1047. doi:10.1111/ggi.13118

Pegg, S. (2009). Marketing the Leisure Experience to Baby Boomers and Older Tourists AU Patterson, Ian. Journal of Hospitality Marketing \& Management, 18(2-3), 254-272. Retrieved from https://doi.org/10.1080/19368620802594136. doi:10.1080/19368620802594136

Pesonen, J., \& Komppula, R. (2010). Rural Wellbeing Tourism: Motivations and Expectations. Journal of Hospitality and Tourism Management, 17(1), 150-157. Retrieved from http://www.sciencedirect.com/science/article/pii/S1447677000000747. doi: https://doi.org/10.1375/jhtm.17.1.150

Sawińska, A. (2017). INNOVATIONS OF TRAVEL AGENCIES IN TOURISM SERVICES FOR SENIORS. Tourism in Southern \& Eastern Europe, 4, 511-523. Retrieved from https://ejournal.mahidol.ac.th/login?url=http://search.ebscohost.com/login.aspx?direct $=$ true $\& \mathrm{db}=$ hjh $\& \mathrm{AN}=126385602 \&$ site $=$ ehost-live. doi:10.20867/tosee. 04.28

Thomas, S., Chie, Q. T., Abraham, M., Raj, S. J., \& Beh, L.-S. (2014). A Qualitative Review of Literature on Peer Review of Teaching in Higher Education: An Application of the SWOT Framework. Review of Educational Research, 84(1), 112-159.

Valentin, E. K. (2001). Swot Analysis from a Resource-Based View. Journal of Marketing Theory and Practice, 9(2), 54-69.

Wang, W., Yi, L., Wu, M.-Y., Pearce, P. L., \& Huang, S. (2018). Examining Chinese adult children's motivations for traveling with their parents. Tourism Management, 69, 422433. 
http://www.sciencedirect.com/science/article/pii/S0261517718301353.

doi:https://doi.org/10.1016/j.tourman.2018.06.024

Woo, E., Kim, H., \& Uysal, M. (2016). A Measure of Quality of Life in Elderly Tourists. Applied Research in Quality of Life, 11(1), 65-82. Retrieved from https://doi.org/10.1007/s11482-014-9355-x. doi:10.1007/s11482-014-9355-x

Zhang, L., \& Zhang, J. (2018). Impacts of Leisure and Tourism on the Elderly's Quality of Life in Intimacy: A Comparative Study in Japan. Sustainability, 10(12). doi:10.3390/su10124861 